\title{
Penguatan Nilai-Nilai Kewirausahaan dan Pendidikan Karakter bagi Mahasiswa PAI IAIN Surakarta
}

\section{Rohmat \\ IAIN Surakarta}

\begin{abstract}
The study aims to determine the strengthening of the entrepreneurial and character education values in preparing graduates in a synergy with competency standard of Junior High School (SMP) students for the Undergraduate Students of the Islamic Education Department (PAI), Faculty of Islamic Education and Teacher Training (FITK) of IAIN Surakarta 2016. The study used quantitative approach. It was conducted in the second semester students of the PAI Department of FITK IAIN Surakarta 2016. The data was collected using questionnaires given to 159 respondents. The data was processed using the requirements and hypotheses test. The result of the study indicates that all questionnaires items declared valid and reliable.
\end{abstract}

\begin{abstract}
Abstrak
Penelitian ini dilakukan untuk mengetahui penguatan nilai-nilai kewirausahaan dan pendidikan karakter terhadap penyiapan lulusan sinergi dengan standar kompetensi lulusan jenjang SMP bagi mahasiswa strata satuJurusan Pendidikan Agama Islam (PAI), Fakultas IImu Tarbiyah dan Keguruan (FITK), IAIN Surakarta, Tahun 2016. Pendekatan penelitian ini menggunakan kuantitatif. Penelitian dilakukan pada mahasiswa semester genap Jurusan PAI, FITK IAIN Surakarta tahun 2016. Pengumpulan data menggunakan angket yang diberikan kepada I59 responden. Data diolah dengan menggunakan uji persyaratan dan uji hipotesis. Hasil penelitian ini menunjukkan bahwa seluruh item-item angket dinyatakan valid dan reliabel.
\end{abstract}

Keywords: Entrepreneurial values, character education, and competency standards. 


\section{Pendahuluan}

Pembangunan manusia Indonesia seutuhnya menemukan momentumnya pada era orde baru. Dekade ini dirasakan sebagai babak dimulainya jaman informasi komunikasi. Dewasa ini juga sebagai arena persaingan, tidak hanya materi ekonomi melainkan juga nilai-nilai kewirausahaan perlu melekat dalam membangun pertumbuhan ekonomi bangsa. Abad 21, dalam Masyarakat Ekonomi Asean (MEA) dituntut untuk membudayakan NilaiNilai Kewirausahaan (NK) diantaranya; kerja keras, disiplin, tanggungjawab dan lainnya. Hal ini menuju karakter/budi pekerti menunjukkan etika yang baik dan sangat urgen bagi diri seseorang agar dirinya eksis pada waktu berhubungan dengan orang lain. Karakter/ budi pekerti merupakan nilai-nilai yang khas, yang baik, berbuat baik dalam kehidupan yang berdampak positif atau baik bagi lingkungan tempat tinggalnya (Amin 2011, 3). Hal ini menegaskan bahwa setiap manusia sangat perlu menjalani proses baik di luar sekolah maupun dalam prosessi akademik. Prosesi akademik bukan semata mata materi pelajaran yang diterima sebagai pengetahuan melainkan juga perilaku perwujudan NK dan Aspekaspek Pendidikan Karakter (APK). Untuk itu, manusia perlu melaksanakan aktivitasnya bertumpu kepada NK dan APK. Demikian halnya, bagi mahasiswa perlu ditumbuhkan sentuhan nilai itu dalam prosesi akademik.

Pemahaman mahasiswa/i tentang Nilai-Nilai Kewirausahaan (NK) terkesan masih terbatas. Nilai-nilai kewirausahaan meliputi; commitment, confidence, cooperative, care, creative, challenge, calculation, communicatoins, competitiviness, change. (Rohmat 2013, 72 73). Sepuluh NK itu seyogyanya inheren dalam menguatkan proses akademik sehingga pada gilirannya menjadikan mahasiswa/i memiliki kepribadian mandiri setelah lulus. Seterusnya, terdapat fenomena juga, yang terkesan kepada materi saja kurang dalam perilaku tentang penguatan Aspek-Aspek dalam Pendidikan Karakter (APK). Instruksi Presiden RI nomor satu tahun 2010 tentang percepatan pelaksanaan prioritas pembangunan nasional tahun 2010 merupakan dasar hukum yang penting bahwa membangun karakter/budi pekerti bangsa. Pemerintah melalui materi-materinya sekarang ini bertekad membangunkan karakter/budi pekerti bangsa yang sedang tidur sebagai salah satu fokus utama membangun nasional. Selanjutnya, pendidikan karakter mencakup diantaranya; religious, jujur, disiplin, kerja keras, kreatif, mandiri, demokrasi, menghargai prestasi, peduli lingkungan, peduli sosial, dan tanggungjawab.

Penyiapan sebagai sarjana PAI secara akademik nampak, tetapi belum menunjukkan jawaban terhadap kondidisi nyata pada bidang garapannya. Keadaan riil seperti; pengamatan tentang PAI pada SMP, pengajuan pertanyaan ke PAI- an pada SMP, mengkaitkan konstruk teoritik program strata satu PAI mengenai ilmu pengetahuan dan teknologi yang telah diperoleh dalam studi dengan bidang garapan PAI pada SMP, melakukan penjelajahan 
kurikuler PAI SMP sampai dengan standar kelulusannya, dan merumuskan pernyataan komunikasi sehingga terjadi sinergi lulusan PAI dengan bidang garapannya juga belum dilakukan.

Penyiapan lulusan strata satu bagi mahasiswa Jurusan PAI FITK berorientasi kepada sinergi standar kelulusan SMP dengan kompetensi lulusan SMP mencakup diantaranya; Mengamalkan ajaran agama yang dianut sesuai dengan tahap perkembangan remaja; Memahami kekurangan dan kelebihan diri sendiri; Menunjukkan sikap percaya diri; Mematuhi aturan-aturan sosial yang berlaku dalam lingkungan yang lebih luas; Menghargai keberagaman agama, budaya, suku, ras, dan golongan sosial ekonomi dalam lingkup nasional. Sandar kompetensi kelulusan SMP tersebut terkesan juga belum sepenuhnya bahkan disinyalir sangat tipis tentang penyiapan lulusan strata satu PAI FITK. Sehubungan dengan hal di atas, maka layak untuk dilakukan mengenai; penguatan nilai-nilai kewirausahaan dan pendidikan karakter terhadap penyiapan lulusan sinergi standar kompetensi lulusan jenjang SMP bagi mahasiswa Jurusan PAI FITK IAIN Surakarta tahun 2016.

\section{Nilai-Nilai Kewirausahaan}

Nilai-nilai dalam kehidupan bersifat universal. Namun demikian, terdapat nilainilai spesifikasi seperti, NK. NK sejalan dengan nilai-nilai universal. Perwujudan nilai-nilai universal dalam nilai murni kewirausahaan dapat diungkapkan diantaranya; komitmen, percaya diri, kerjasama dan lain sebagainya. NK mencakup 10 unsur. Kesepuluh itu yakni: commitment, confidence, cooperative, care, creative, challenge, calculation, communicatoins, competitiviness, change. Sepuluh NK di atas seyogyanya inhern dalam menumbuhkan jiwa wirausaha sehingga pada gilirannya menjadikan usahawan berwirausaha menjadi berjaya. Sekalipun demikian, tidak mudah untuk dilakukan akan tetapi bisa dikerjakan. Sehubungan dengan hal itu, pemahaman nilai-nilai tersebut perlu ditumbuh-kembangkan dalam setiap perilaku kehidupan manusia. Nilai-nilai itu akan memberikan sentuhan kepada potensi akademik diri setiap manusia. Untuk memperjelas mengenai $10 \mathrm{C}$ berikut dipaparkan satu per satu.

\section{a. Commitment/ Komitmen}

Komitmen diri dalam bahasa yang lain memiliki keinginan, minat, kemauan, dan motivasi untuk berwirausaha. Bilamana dicermati maka hal itu mempunyai niat untuk berwirausaha. Nilai ini penting, sebab segala sesuatu perbuatan yang dilakukan tergantung pada niatnya.

b. Confidence/ Percaya Diri

Percaya diri bagi seorang wirausaha merupakan sebuah daya yang mampu memberikan dukungan kemantapan dalam mengambil keputusan (Djokoaw2007). 
Sehubungan hal itu, stabilitas emosional tetap dijadikan rujukkan. Percaya diri sebagai suatu sikap positif seorang individu yang memiliki kemampuan untuk mengembangkan penilaian positif baik terhadap diri sendiri maupun terhadap lingkungan atau situasi yang dihadapinya, sehingga dengan alasan ini, akan mampu melakukan tindakan sesuai dengan yang diinginkan, dalam merencanakan dan harapkan (Nimahsyifa 2013).

c. Cooperative/ Kerjasama

Dasar dari wirausaha berkembang dan sukses bertumpu pada suatu ketrampilan komunikasi, jaringan dan kerjasama yang baik. Selain itu, jaringan yang baik dapat berperan dalam meningkatkan dan menyebarkan wirausaha yang luas, memberikan dorongan signifikan terhadap keuntungan.

d. Care/ Teliti

Dalam melakukan usaha memerlukan tindakan cermat, teliti untuk pertumbuhan ekonomi dengan mengharapkan ridho ilahi. Teliti berarti cermat dan hati-hati. Teliti termasuk akhlak mahmudah yang harus dimiliki setiap muslim utamanya usahawan muslim. Orang yang senantiasa cermat dan teliti dalam setiap perbuatan maka kemungkinan besar akan terhindar dari kesalahan dan kerugian. Islam melarang umatnya tergesa-gesa dan berlaku sembarangan dalam tindak tanduknya, sebab sikap tergesa-gesa itu sebagai tindak tanduk setan.

e. Creative/ Kreatif

Seorang wirausahawan tidak hanya dapat berencana, berkata-kata tetapi juga berbuat, Untuk itu, dibutuhkan kreativitas, mengenai pola pikir sesuatu yang baru, dan tindakan dalam melakukan sesuatu yang baru (Vanirawan 2011). Selanjutnya, dikatakan bahwa kreativitas merupakan kemampuan untuk memberikan gagasan-gagasan baru dan menerapkannya dalam pemecahan masalah.

f. Challenge/ Tantangan

Tantangan bukan dipandang sebagai hambatan melainkan merupakan liku-liku dalam perjalanan kehidupan, hidup itu ujian. Kehidupan yakni perjalanan. Usahawan memaknai perjalanannya menghadapi berbagai varians kehidupan. Untuk itu, perlu mengenal varians tersebut merupakan kawan bukan lawan. Selanjutnya, dinyatakan tidak banyak wirausahawan yang menyadari beratnya tantangan yang dihadapi, terutama saat pertama kali merintis usahanya (Gondokusumo 2013).

g. Calculation/ Perhitungan

Usahawan perlu melakukan perhitungan matang agar terhindar dari kerugian. Perhitungan yang dimaksud sangat standart misalnya, hari ini dalam melakukan usaha jangan impas, bahkan lebih jelek dari hari sebelumnya. Tentunya hari ini lebih baik dari hari kemarin, inilah usahawan perlu mengemban usahanya dengan senantiasa memperhitungkan semakin hari semakin meningkat hasilnya, dengan kata lain 
melakukan usaha semakin hari semakin mendapatkan hasil yang lebih baik.

h. Communication/ Komunikasi

Dalam komunikasi harus ramah, supel, tidak kaku. Perspektif Islam, komunikasi merupakan bagian yang tidak terpisahkan dalam kehidupan manusia. Ini dipahami bahwa segala gerak langkah manusia selalu disertai dengan komunikasi. Komunikasi yang dimaksud adalah komunikasi yang islami, yaitu komunikasi berakhlak al-karimah atau beretika. Komunikasi yang berakhlak al-karimah berarti komunikasi yang bersumber kepada Al-Quran dan hadits.

h. Competitiviness/ Daya Saing

Siap menghadapi persaingan baik di lingkungan sendiri maupun lingkungan luas, termasuk lingkungan lokal, regional, nasional, maupun internasional. Dunia bisnis persaingan menjadi sesuatu hal yang tidak bisa dielakkan. Setiap pelaku wirausaha selalu meningkatkan daya saing usahanyanya dari waktu ke waktu. Berbagai macam strategi dan teknik dipakai untuk memenangkan persaingan yang kadang memang sangat menguras tenaga dan pikiran bahkan materi. Munculnya pesaing-pesaing baru yang semakin banyak turut memberi andil betapa pentingnya selalu meningkatkan daya saing.

i. Change/ Berubah

Inovasi inkremental terlihat pada sektor kerja, yaitu: (a) Knowledge-intensive service (KIS), usahanya meliputi pengembangan ekonomi, contoh: konsultan akuntasi, administrasi, R\&D service, teknik, komputer, dan manajemen. Sumber utama inovasi dari kemampuan mereka untuk memberikan hasil desain yang sesuai untuk pengguna layanan mereka; (b) Supplier-dominated services (SDS), meliputi perdagangan retail, pelayanan pribadi (seperti potong rambut), hotel dan restaurant. Selanjutnya, macam inovasi berdasarkan fungsi adalah inovasi teknologi dapat berupa produk, pelayanan atau proses produksi dan inovasi administrasi dapat bersifat organisasional, struktural, dan inovasi social (Jong \&Hartog 2003).

\section{Pendidikan Karakter}

Pendidikan karakter dimaknai sebagai berikut: "character education is the deliberate effort to help people understand, care about, and act upon core ethical values. When we think about the kind of character we want for our children, it is clear that we want them to be able to judge what is right, care deeply about what is right, and then do what they believe to be right, even in the face of pressure from without and temptation from within"(Elkind \& Sweet2004).

Lebih lanjut dijelaskan, pendidikan karakter memiliki esensi dan makna yang sama dengan pendidikan moral dan pendidikan akhlak (Ramli 2003). Tujuannya adalah membentuk pribadi anak, supaya menjadi manusia yang baik, warga masyarakat, dan warga negara yang baik. Adapun kriteria manusia yang baik, warga masyarakat yang baik, dan warga 
negara yang baik bagi suatu masyarakat atau bangsa, secara umum adalah nilai-nilai sosial tertentu, yang banyak dipengaruhi oleh budaya masyarakat dan bangsanya. Oleh karena itu, hakikat dari pendidikan karakter dalam konteks pendidikan di Indonesia adalah pedidikan nilai, yakni pendidikan nilai-nilai luhur yang bersumber dari budaya bangsa Indonesia sendiri, dalam rangka membina kepribadian generasi muda. 18 nilai pengembangan budaya dan karakter bangsa, yaitu: religius, jujur, toleransi, disiplin, kerja keras, kreatif, mandiri, demokratis, rasa ingin tahu, semangat kebangsaan, cinta tanah air, menghargai prestasi, brrsahabat/ komunikatif, cinta damai, gemar membaca, peduli lingkungan, peduli sosial dan tanggung jawab.

\section{Standar Kompetensi Lulusan SMP}

Lulusan SMP memiliki kompetensi-kompetensi sebagaiberikut:a) Mengamalkan ajaran agama yang dianut sesuai dengan tahap perkembangan remaja; b) Memahami kekurangan dan kelebihan diri sendiri; c)Menunjukkan sikap percaya diri; d) Mematuhi aturan-aturan sosial yang berlaku dalam lingkungan yang lebih luas; e) Menghargai keberagaman agama, budaya, suku, ras, dan golongan sosial ekonomi dalam lingkup nasional; f) Mencari dan menerapkan informasi dari lingkungan sekitar dan sumber-sumber lain secara logis, kritis, dan kreatif; g) Menunjukkan kemampuan berpikir logis, kritis, kreatif, dan inovatif; h) Menunjukkan kemampuan belajar secara mandiri sesuai dengan potensi yang dimilikinya; i) Menunjukkan kemampuan menganalisis dan memecahkan masalah dalam kehidupan sehari-hari; j) Mendeskripsikan gejala alam dan sosial; k) Memanfaatkan lingkungan secara bertanggung jawab; 1) Menerapkan nilai-nilai kebersamaan dalam kehidupan bermasyarakat, berbangsa, dan bernegara demi terwujudnya persatuan dalam Negara Kesatuan Republik Indonesia; m) Menghargai karya seni dan budaya nasional; n) Menghargai tugas pekerjaan dan memiliki kemampuan untuk berkarya; o) Menerapkan hidup bersih, sehat, bugar, aman, dan memanfaatkan waktu luang dengan baik; p) Berkomunikasi dan berinteraksi secara efektif dan santun; q) Memahami hak dan kewajiban diri dan orang lain dalam pergaulan di masyarakat; Menghargai adanya perbedaan pendapat; r) Menunjukkan kegemaran membaca dan menulis naskah pendek sederhana; s) Menunjukkan keterampilan menyimak, berbicara, membaca, dan menulis dalam bahasa Indonesia dan bahasa Inggris sederhana; t) Menguasai pengetahuan yang diperlukan untuk mengikuti pendidikan menengah; u) Memiliki jiwa kewirausahaan.

\section{Penguatan NK Terhadap Penyiapan Lulusan Sinergi SKL SMP}

Pengembangan karakter dalam suatu sistem pendidikan adalah keterkaitan antara komponen-komponen karakter yang mengandung nilai-nilai perilaku, yang dapat dilakukan atau bertindak secara bertahap dan saling berhubungan antara pengetahuan nilai-nilai 
perilaku dengan sikap atau emosi yang kuat untuk melaksanakannya, baik terhadap Tuhan YME, dirinya, sesama, lingkungan, bangsa dan negara serta dunia internasional. Dengan demikian, NK memiliki keterkaitan dalam memberikan dasar alamiah kepada pembentukan kepribadian lulusan, termasuk lulusan yang dipersiapkan sinergi dengan SKL jenjang SMP.

\section{Penguatan APK Terhadap Penyiapan Lulusan Sinergi SKL SMP}

APK terintegrasi dalam semua pelajaran. Dengan demikian, APK baik langsung maupn tidak langsung membudaya dalam setiap pelajaran. Apresiasi ini menunjukkan bahwa keterkaitan pelajaran bukan berkembangnya materi pengetahuan melainkan juga APK. Demikianhalnya dengan penguatan APK terhadap lulusan sinergi SKL SMP.

\section{Pengutan NK dan APK Terhadap Penyiapan Lulusan Sinergi SKL SMP}

NK sejalan dengan karakter dalam penyiapan lulusan sinergi dengan SKL SMP. Hal ini ) dipandang sebagai tata nilai budaya dan keyakinan yang mengejawantah dalam kebudayaan suatu masyarakat dan memancarkan ciri-ciri khas keluar sehingga dapat direspon orang luar sebagai kepribadian masyarakat tersebut. Pada hakikatnya, pendidikan tidak sekedar bertujuan untuk membuat orang menjadi pintar, lebih dari itu, pendidikan juga memiliki misi untuk membuat orang menjadi baik (Armando 2008,8).Oleh itu, sangat diperlukan NK dan APK yang bersumber pada nilai-nilai kehidupan, Agama, Pancasila, Budaya dan Tujuan Pendidikan Nasional. Berdasarkan hal itu perlu dirumuskan penguatannya terhadap lulusan sinergi dengan SKL SMP.

\section{Metode penelitian}

Desain penelitian ini menggunakan pendekatan kuantitatif. Data kuantitatifmerupakan data-data yang disajikan dalam bentuk angka-angka yang perlu dikuantitatifkan dalam pengolahan data sehingga mempermudah perhitungannya (Sugiyono2010,31).Adapun desain dalam penelitian ini digambarkan pada bagan sebagai berikut:

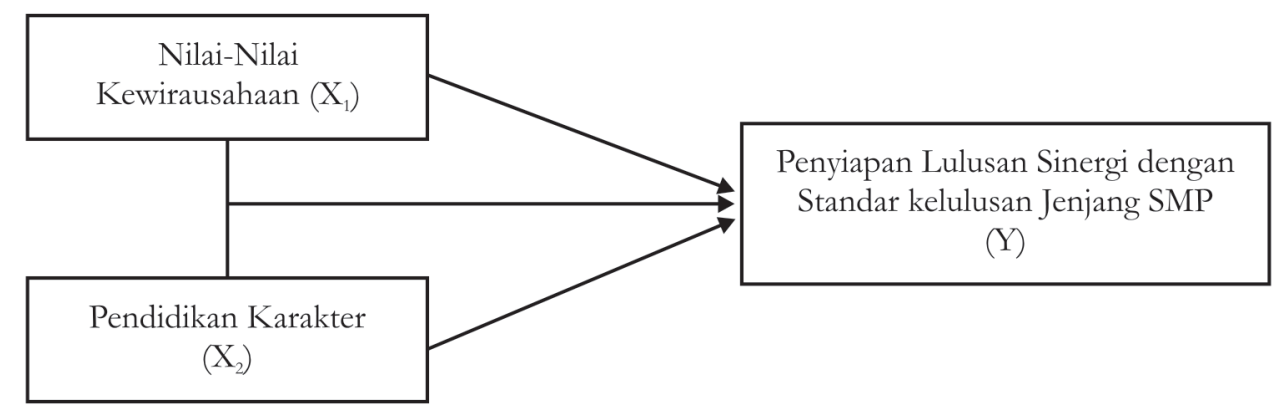


Tempat penelitian, penelitian ini dilakukan pada mahasiswa jurusan PAI FITK di IAIN Surakarta tahun 2016 dan waktu penelitian, penelitian dilaksanakan pada bulan April s.d Mei 2016.

Pengambilan sampel didasarkan atas pendapat yang dikemukakan, apabila subjeknya besar dapat diambil antara 10\%-15\% atau 20\%-30\% atau lebih (Supriyanto, 2009: 123). Sehubungan dengan terbatasnya waktu, biaya dan hal lainnya, maka dalam penelitian ini peneliti mengambil sampel sejumlah 30\% atau 150 mahasiswa sebagai responden dari populasi mahasiswa Jurusan PAI FITK IAIN Surakarta tahun 2016.

Jenis data kuantitatif yang digunakan dalam penelitian ini adalah data primer. Data Primer yaitu data yang dikumpulkan dan diolah sendiri oleh peneliti langsung dari responden (Supriyanto, 2009: 133). Teknik pengumpulan data yang dilakukan dalam penelitian ini adalah kuesioner. Teknis analisis data ini menggunakan analisis regresi linier berganda. Adapun langkah untuk menguji hipotesis secara keseluruhan pada penelitian ini sebagai berikut: Uji Statistik Deskriptif; Uji Asumsi Klasik dengan tahapan: Uji Normalitas; Uji Multikolonieritas; Uji Heteroskedastisitas, dan Uji Hipotesis dengan persamaan: $Y=\alpha+$ $\beta_{1} \cdot X_{1}+\beta_{2} \cdot X_{2}+e(Y=$ penyiapan lulusan sinergi dengan standar kelulusan jenjang SMP; $X 1=$ nilai-nilai kewirausahaan; X2= pendidikan karakter).

Analisis regresi yang dilakukan untuk mengetahui seberapa besar penguatan antar variabel independen terhadap variabel dependen. Pengujian statistik yang perlu dilakukan adalah: Uji Ketepatan Perkiraan Model/ Koefisien Determinasi $\left(\mathrm{R}^{2}\right)$; Uji Signifikansi Simultan (Uji F); dan Uji Signifikansi Parameter Individual (Uji t).

\section{Hasil Penelitian}

\section{Deskripsi Data}

Populasi penelitian ini berjumlah 700 mahasiswa. Data dikumpulkan dengan menggunakan angket. Pemilihan responden dilakukan secara random sampling dan diambil sebesar 23\% dari populasi, responden dalam penelitian ini berjumlah 159 mahasiswa jurusan PAI FITK di IAIN Surakarta tahun 2016. Data yang diperoleh sebagai data interval, ini bermakna data hasil pengukuran yang dapat diurutkan atas dasar kriteria yang telah ditentukan dalam angket.

\section{Pengujian Persyaratan}

Untuk memberi kepastian bahwa parameter dalam model yang digunakan memiliki ketepatan dalam estimasi, tidak bias, dan konsisten, maka perlu dilakukan uji asumsi klasik dari regresi model. Dengan demikian tidak terjadi penyimpangan terhadap asumsi normalitas, multikolonieritas dan heteroskedastisitas. Untuk menguji adanya penyimpangan 
asumsi klasik digunakan alat bantu dengan program SPSS 21 .

\section{Uji Validitas dan Reliabilitas}

Uji signifikansi dilakukan dengan membandingkan nilai $r$ hitung dengan $r$ tabel untuk degree offreedom $(\mathrm{df})=\mathrm{n}-2$, dalam hal ini $\mathrm{n}$ adalah sampel. Pada penelitian ini jumlah sampel $(\mathrm{n})=159$ dan besarnya $\mathrm{df}$ dapat dihitung 159-2 dengan $\mathrm{df}=157$ dan alpha $=0.05$ didapat $r_{\text {tabel }}=0,1557$. Berdasarkan hasil penelitian dari 159 responden melalui 95 item pernyataan, menghasilkan bahwa semua item/ pernyataan dinyatakan valid. Sedang berdasarkan hasil penelitian dari 159 responden melalui 95 item pernyataan, menghasilkan bahwa setiap pernyataan dinyatakan reliabel.

\section{Uji Normalitas}

Dari perhitungan diperoleh nilai kolmogorov-smirnov z sebesar 0,648 dan asymp. signifikansi sebesar 0,796. Maka dapat disimpulkan data terdistribusi normal karena 0,796 $>0,05$. Hasil data berdistribusi secara normal berarti tidak terdapat nilai ekstrim dari data yang diambil atau tidak terdapat data yang melenceng terlalu tinggi ataupun terlalu rendah. Hal ini juga mengindikasikan tidak terjadi kesalahan dalam pengambilan sampel dan tidak terdapat kesalahan dalam input data.

\section{Uji Multikolonieritas}

Hasil uji multikolonieritas mendapatkan nilai Variance Inflantion Factors (VIF) lebih kecil dari 10 dan nilai tolerace lebih besar dari 0,10. Maka tidak terjadi multikolonieritas di antara variabel independen. Hal ini berarti tidak terjadi kolerasi yang kuat (hampir sempurna) antar variabel nilai-nilai kewirausahaan dan pendidikan karakter. Sehingga tidak terdapat suatu hubungan linier antar variabel independen dan variabel-variabel independen hanya mempengaruhi variabel dependen saja.

\section{Uji Heteroskedastisitas}

Hasil pengujian pada probabilitas 5\% menunjukkan nilai signifikansi nilai-nilai kewirausahaan sebesar 0,432 dan signifikansi pendidikan karakter sebesar 0,06. Maka dapat disimpulkan variabel nilai-nilai kewirausahaan dan variabel pendidikan karakter tidak ada masalah heteroskedastisitas. Hal ini menunjukkan bahwa varians dari setiap variabel independen adalah sama dan mempunyai angka konstan tertentu. 


\section{Pengujian Hipotesis}

Hasil Regresi Linier Berganda

\begin{tabular}{|l|c|c|c|}
\hline \multicolumn{1}{|c|}{ Variabel } & Koef. Regresi & $\mathbf{t}_{\text {hitung }}$ & Sig. \\
\hline Constant & 33,366 & 3,142 & 0,002 \\
\hline Nilai-nilai Kewirausahaan & 0,431 & 2,692 & 0,008 \\
\hline Pendidikan Karakter & 1,043 & 9,042 & 0,000 \\
\hline
\end{tabular}

Sumber: olah data SPSS, 2016

Hasil pengolahan data regresi linier berganda dengan menggunakan program SPSS 21 dapat dilihat pada tabel di atas. Dari tabel tersebut dapat disusun persamaan regresi linier berganda sebagai berikut:

$\mathrm{Y}=33,366+0,431 \mathrm{X}_{1}+1,043 \mathrm{X}_{2}+\mathrm{e}$

Keterangan:

$\mathrm{Y}=$ Penyiapan Lulusan sinergi Standar Kompetensi Lulusan Jenjang SMP

$\mathrm{X}_{1}=$ Nilai-nilai Kewirausahaan

$\mathrm{X}_{2}=$ Pendidikan Karakter

Dari persamaan linier regresi berganda di atas dapat diuraikan sebagai berikut:

a. Nilai konstan bernilai 33,366 dengan nilai positif. Hal ini menunjukkan bahwa apabila variabel nilai-nilai kewirausahaan dan pendidikan karakter sama dengan nol, maka penguatan penyiapan lulusan sinergi dengan standar kompetensi lulusan jenjang SMP sebesar 33,366.

b. Koefisien regresi variabel nilai-nilai kewirausahaan $\left(\beta_{1}\right)$ sebesar 0,431 . Hal ini menunjukkan bahwa setiap peningkatan nilai-nilai kewirausahaan sebesar 1 satuan maka akan memberi dampak terhadap penguatan penyiapan lulusan sinergi dengan standar kompetensi lulusan jenjang SMP sebesar 0,431 dengan asumsi variabel yang lain konstan.

c. Koefisien regresi variabel pendidikan karakter $\left(\beta_{2}\right)$ sebesar 1,043 . Hal ini menunjukkan bahwa setiap peningkatan pendidikan sebesar 1 satuan, maka akan memberikan dampak terhadap penguatan penyiapan lulusan sinergi dengan standar kompetensi lulusan jenjang SMP sebesar 1,043 dengan asumsi variabel lain konstan.

Dari persamaan di atas selanjutnya akan dilakukan pengujian-pengujian sebagai berikut:

\section{a. Uji F}

Dari olah data diperoleh nilai signifikansi sebesar $0,000<0,05$, maka dapat disimpulkan bahwa model regresi fit sehingga secara simultan nilai-nilai kewirausahaan 
dan pendidikan karakter secara bersama-sama berpengaruh terhadap penguatan penyiapan lulusan sinergi dengan standar kompetensi lulusan jenjang SMP.

\section{b. Uji Parsial (Uji t)}

\section{Hasil Uji t}

\begin{tabular}{|l|c|c|c|c|}
\hline \multicolumn{1}{|c|}{ Variabel } & $\mathbf{t}_{\text {hitumg }}$ & $\mathbf{t}_{\text {tabel }}$ & Sig. & Kesimpulan \\
\hline $\begin{array}{l}\text { Nilai-nilai } \\
\text { Kewirausahaan }\end{array}$ & 2,692 & 1,654 & 0,008 & Signifikan \\
\hline Pendidikan Karakter & 9,042 & 1,654 & 0,000 & Signifikan \\
\hline
\end{tabular}

Sumber: olah data SPSS, 2016

Dari tabel di atas dapat diketahui bahwa variabel nilai-nilai kewirausahaan mempunyai $t_{\text {hitung }}$ 2,692 lebih besar dari $t_{\text {tabel }}$ 1,654 dan diperoleh nilai signifikansi sebesar 0,008 lebih kecil dari taraf signifikansi 0,05 $(0,008<0,05)$. Oleh karena itu, dapat disimpulkan bahwa nilai-nilai kewirausahaan menguatkan secara signifikan terhadap penyiapan lulusan sinergi dengan standar kompetensi lulusan jenjang SMP, maka $\mathrm{H}_{1}$ diterima.

Berdasarkan hasil perhitungan diketahui bahwa variabel pendidikan karakter mempunyai $t_{\text {hitung }} 9,042$ lebih besar dari $t_{\text {tabel }}$ sebesar 1,654 dan diperoleh nilai signifikansi 0,000 lebih kecil dari taraf signifikansi $0,05(0,000<0,05)$. Oleh karena itu, dapat disimpulkan bahwa pendidikan karakter mempunyai penguatan positif dan signifikan terhadap penyiapan lulusan sinergi dengan kompetensi lulusan jenjang SMP, maka $\mathrm{H}_{2}$ diterima.

\section{Koefisien Determinasi $\left(\mathbf{R}^{2}\right)$}

Koefisien determinasi $\left(\mathrm{R}^{2}\right)$ pada intinya mengukur seberapa jauh kemampuan model dalam menerangkan variasi variabel dependen. Adapun hasil koefisien determinasi $\left(\mathrm{R}^{2}\right)$ terlihat pada tabel berikut:

Hasil Koefisien determinasi $\left(\mathbf{R}^{2}\right)$

\begin{tabular}{|c|c|c|c|}
\hline $\mathbf{R}$ & R-Square & Adj R-Square & $\begin{array}{c}\text { Std eror of the } \\
\text { Estimate }\end{array}$ \\
\hline 0,788 & 0,621 & 0,616 & 10,177 \\
\hline
\end{tabular}

Sumber: olah data SPSS, 2016

Dari tabel di atas diperoleh R-Square sebesar 0,621 yang berarti sebesar 62,1\% penyiapan lulusan sinergi dengan standar kompetensi lulusan jenjang SMP dapat dijelaskan oleh komposisi variabel independen yaitu nilai-nilai kewirausahaan dan pendidikan karakter. Sedangkan 37,9\% dijelaskan oleh variabel diluar model penelitian ini. 


\section{Pembahasan}

Berdasarkan Uji F diketahui bahwa variabel independen yang terdiri dari nilai-nilai kewirausahaan dan pendidikan karakter secara simultan mempunyai dampak penguatan positif secara statistik terhadap penyiapan lulusan sinergi dengan standar kompetensi lulusan jenjang SMP. Sedang berdasarkan uji parsial kedua variabel independen tersebut memiliki dampak penguatan terhadap variabel dependen. Variabel nilai-nilai kewirausahaan akan memberi penguatan sebesar 0,431 pada setiap kenaikannya, dan variabel pendidikan karakter akan memberi penguatan sebesar 1,043 terhadap persiapan lulusan sinergi dengan standar kompetensi lulusan jenjang SMP.

Hal ini sesuai dengan yang diungkapkan oleh Winarno, bahwa pendidikan yang berbasis kewirausahaan merupakan pendidikan yang menerapkan prinsip-prinsip dan metodologi ke arah internalisasi nilai-nilai pada peserta didiknya melalui kurikulum yang terintegrasi dengan perkembangan yang terjadi baik di lingkungan pendidikan maupun lingkungan masyarakat serta penggunaan model dan strategi pembelajarannya. Lembaga pendidikan tidak hanya bertugas melahirkan banyaknya lulusan, akan tetapi yang jauh lebih penting yaitu seberapa besar lulusannya itu dapat menolong dirinya sendiri dalam menghadapi tantangan di masyarakat atau dengan kata lain sekolah harus meningkatkan kecakapan lulusannya, yang ditempuh melalui pendidikan berbasis nilai-nilai kewirausahaan (Winarno 2011,124).

Sejalan dengan yang diungkapkan oleh Fulgence, enterpreneurship should be viewed from a broader prespective and not limited to the tradisional view limiting it to business creation. The new view proposes that beside focusingon specific situations (new venture creation), entrepreneurship education should also focus on behaviour (entrepreneurial behaviour) and mindset (entrepreneurial mindset, spirit or attitude) (Katherine 2015,57.2). Kewirausahaan dapat dilihat dari perspektif yang lebih luas dan tidak terbatas pada pandangan untuk penciptaan bisnis. Pandangan baru mengusulkan bahwa selain fokus pada situasi tertentu (penciptaan usaha baru), pendidikan kewirausahaan juga fokus pada perilaku kewirausahaan dan pola pikir (nilai-nilai kewirausahaan, semangat dan sikap).

Dalam konteks lain Wanda juga menuliskan bahwa pendidikan karakter penting untuk diterapkan dalam pendidikan formal. Universitas sebagai lembaga pendidikan tinggi merupakan salah satu sumber daya yang penting, maka harus diajarkan kebiasaan cara berfikir dan perilaku yang membantu individu untuk hidup dan bekerjasama sebagai keluarga, masyarakat, dan bernegara serta membantu individu untuk membuat keputusan yang dapat dipertanggungjawabkan (Chrisiana 2005).

Sejalan dengan yang diungkapkan Trisiana, value as character building pillar as like government policy that simultaneously and synergetic will srteng then the nation character, so in character education learning can integrate character values as well as emerge citizen 
understanding and behaviour which are able to reflect moral value (Trisiana2015). Nilai moral berperan sebagai pembentuk karakter seperti kebijakan pemerintah yang secara bersamaan dan sinergis memperkuat karakter bangsa, sehingga dalam pembelajaran pendidikan karakter dapat mengintegrasikan nila-nilai karakter serta muncul pemahaman dan perilaku yang mencerminkan nilai moral sebagai warga negara.

\section{Kesimpulan}

Hasil penelitian ini dapat dikemukakan sebagai berikut. Nilai-nilai kewirausahaan diprediksi memberikan penguatan positif terhadap penyiapan lulusan sinergi dengan standar kompetensi lulusan jenjang SMP sebesar 0,431. Pendidikan karakter diprediksi memberikan penguatan positif terhadap penyiapan lulusan sinergi dengan standar kompetensi lulusan jenjang SMP sebesar 1,043. Nilai-nilai kewirausahaan dan pendidikan karakter secara simultan memiliki pengaruh terhadap penguatan penyiapan lulusan sinergi dengan standar kompetensi lulusan jenjang SMP sebesar 62,1\%.

Temuan penelitian ini, memiliki implikasi kepada penyelenggara pendidikan pada umumnya, dan khususnya bagi pengelola di FITK dalam rangka penguatan penyiapan lulusan Sarjana PAI yang bermoral dan memiliki nilai-nilai kewirausahaan. Lembaga pendidikan/ institusi, untuk melahirkan lulusan bermutu yang ditempuh melalui pendidikan berbasis nilai-nilai kewirausahaan dan pendidikan karakter untuk menghadapi tantangan di masyarakat. Pendidik untuk terus mengajarkan dan menanamkan nilai-nilai kewirausahaan dan pendidikan karakter pada peserta didik untuk bisa diterapkan dalam kehidupan seharihari. Pembelajar termotivasi untuk mengamalkan nilai-nilai kewirausahaan dengan diiringi pendidikan karakter.

\section{Referensi}

Armando, Ade, dkk. 2008. Refleksi Karakter Bangsa. Forum Kajian Antropologi Indonesia. Jakarta.

Vanirawan, Bagas. 2011. Kewirausahaan Kreativitas Wirausaha Tanpa Henti. http:// bagasvanirawan.wordpress.com/2011/10/06/kewirausahaan-kreativitas-wirausahakreativitas-tanpa-henti/

Djokoaw. 2007. Motivasi dan percaya diri dalam wirausaha. http://djokoawcollection. blogspot.com/2007/11/motivasi-dan-percaya-diri-dalam-wira.html diakses 12 Maret 2014 Jam 08.25 WIB

Jong, De \& Hartog, Den. 2003. Leadership as a determinant of innovative behavior. EIM Business and Policy Research 
Fulgence, Katherine. 2015. Assesing The Status Of Entrepreneurship Education Courses In higher Learning Institutions: The Case Of Tanzania Education Schools. International Journal of Education and Training 57.2

Amin, Maswardi Muhammad. 2011. Pendidikan Karakter Anak Bangsa. Jakarta: Baduose Media

Nimahsyifa. 2013. Konsep Percaya Diri Dalam Islam. http://nimahsyifa.blogspot. com/2013/10/konsep-percaya-diri-dalam-islam-percaya.html

Rohmat. 2013. Manajemen Kepemimpinan Kewirausahaan. Yogyakarta: Cipta Media Aksara

Gondokusumo, Ryan. 2013. Tantangan Untuk Memulai Wirausaha. Blog.sribu. com/2013/10/30/7-tantangan-untuk-memulai-wirausaha/ diakses 25 Maret 2015 Jam 10.05 WIB

Sugiyono. 2014. Metode Penelitian Manajemen. Bandung: Alfabeta

Supriyanto. 2009. Metodologi Riset Bisnis. Jakarta: PT Indeks.

Sekaran, Uma \& Bougie, Roger. 2013. Research Methods for Business. Italy: Printer Trento Srt

Trisiana, Anita. 2015. Action For Citizenship Education Of Character Education using Project Citizen Model At Senior Hight School In Indonesia. International Journal of Education and Psychology in the Community 5.1/ 2

Ramli, T. 2003. Pendidikan Karakter. Bandung: Angkasa.

Chrisiana, Wanda. 2005. Upaya Penerapan Pendidikan Karakter bagi Mahasiswa (Studi Kasus di Jurusan teknik Industri Uk Petra). Jurnal teknik Industri Vol. 7, No. 1

Winarno. 2011. Pengembangan Sikap Entrepreneurship dan intrepreneurship. Jakarta: PT Indeks 